Cornell Law Library

Scholarship@Cornell Law: A Digital Repository

Cornell Law Faculty Publications

Faculty Scholarship

$11-1972$

\title{
External Economies and Competitive Equilibrium
}

George A. Hay

Cornell Law School, george.hay@cornell.edu

John J. McGowan

Yale University

Follow this and additional works at: http://scholarship.law.cornell.edu/facpub

Part of the Econometrics Commons, Industrial Organization Commons, and the Macroeconomics Commons

\section{Recommended Citation}

Hay, George A. and McGowan, John J., "External Economies and Competitive Equilibrium" (1972). Cornell Law Faculty Publications. Paper 1164.

http://scholarship.law.cornell.edu/facpub/1164

This Article is brought to you for free and open access by the Faculty Scholarship at Scholarship@Cornell Law: A Digital Repository. It has been accepted for inclusion in Cornell Law Faculty Publications by an authorized administrator of Scholarship@Cornell Law: A Digital Repository. For more information, please contact jmp8@cornell.edu. 
from the origin, and not just the one that meets the assumptions of Laudadio's transformation function.

The curve in Donaldson and Victor's article which may be more appropriately interpreted as a transformation curve than $O A$ is the $G H$ curve shown in their Figure 3 on page 426. Laudadio might not have been misled if Donaldson and Victor had postulated this curve directly rather than resorting to an unnecessarily complicated derivation involving a second quadrant. ${ }^{1}$

\section{References}

Donaldson, D. and P. Victor. "On the Dynamics of Air Pollution Cortrol." This Journal. III, no. 3 (Aug. 1970), 422-31.

Laudadio, L. "On the Dynamics of Air Pollution: A Correct Interpretation." Ibid. IV, no. 4 (Nov. 1971), 563-71.

Stein, J. J. "The 1971 Report of the President's Council of Economic Advisers: MicroEconomic Aspects of Public Policy." American Economic Review (Sept. 1971).

${ }^{1}$ For example, see Stein (1971), 533

\section{EXTERNAL ECONOMIES AND COMPETITIVE EQUILIBRIUM*}

\section{George A. Hay and John J. McGowan Yale University}

In an article published in $1955,{ }^{1}$ Murray Kemp analyzed the case for interference with the competitive allocation of resources when external economies of production are present. In the specific model we are interested in - where the costs of any one producer's operations are affected by the total output of all producers of the same product ${ }^{2}$ - Kemp attempted to show that where entry into the industry is closed (although the industry is otherwise perfectly competitive), "there can always be found a subsidy, either on the product or on a particular factor, which will be a sufficient incentive to firms to produce an optimal output or to use an optimal quantity of each factor."

However Kemp argues that where there is open cntry, "subsidies are rarely a sufficient remedy for the misallocation of resources resulting from external economies; in many cases found in reality, fiscal controls are impotent to restore an optimal allocation of resources. In the absence of far-reaching changes in the laws safeguarding property rights, the only possible solution [emphasis added] in those cases involves recourse to direct controls." We disagree with this conclusion and intend to show that for the kind of external

*We are grateful to Joseph Stiglitz, Martin Weitzman, and a referee for helpful comments.

'Kemp (1955). One may naturally question the importance of reviving a seventeen-year-old paper for the purpose of criticizing it. Our motive is two-fold. First, Kemp's findings, if true, are an important challenge to neoclassical welfare analysis; and second, Kemp's findings have been revived in a recent article by Goetz and Buchanan (1971).

"Factor costs are assumed constant, so we are considering the case of "rea!" as opposed to "pecuniary" economies.

Canadian Journal of Economics/Revue canadienne d'Economique, V, no. 4

November/novembre 1972. Printed in Canada/I Imprimé au Canada. 
econony discussed by Kemp, even in the case of open entry a simple Pigovian subsidy is sufficient to restore the economy to a Pareto-optimal position. (A similar conclusion applies to external diseconomies where a tax is the policy variable.)

To recap, we are dealing with the case of external economies which are internal to the industry, such that the costs for any one firm vary with the industry's output. Kemp chose a graphical form of analysis which, we will show, was probably responsible for the error. We will attempt to formulate the problem mathematically. The situation is that:

$$
C=C(Q / n, Q) \text {, }
$$

where $C$ is total costs for each firm (all frms are assumed to have the same cost function), $Q$ is total industry output, and $n$ is the number of firms, so that $Q / n$ is the output of each firm. Thus each firm's costs depend not only on its own output but on total industry output as well. ${ }^{3}$ (We are dealing here with "product-generated" externalities. A similar argument holds for "factorgenerated" externalities.)

One condition for Pareto-optimality is that total costs be minimized for whatever level of total output, $Q$, is required. The policy variable is $Q / n$ or, since $Q$ is given, $n$. We choose the latter formulation, and try to minimize total industry costs, $T C$, with respect to $n$, for any given $Q$.

$$
T C=n C(Q / n, Q) \text {. }
$$

For convenience of exposition we treat $n$ as a continuous variable so that we can write ${ }^{4}$

$$
\begin{aligned}
\operatorname{Min}_{n} T C \Rightarrow \partial T C / \partial n & =C+n[\partial C /(\partial Q / n) \cdot(\partial Q / n) / \partial n] \\
& =C-C_{1}(Q / n)=0
\end{aligned}
$$

where $C_{1}=\partial C /(\partial Q / n) . \quad \therefore C=C_{1} \cdot Q / n$, or

$$
C_{1}=C /(Q / n) \text {. }
$$

But $C_{1}$ is private marginal cost $(M C)$ and $C /(Q / n)$ is private average cost $(A C)$, so that the condition for the economy to produce any output $Q$ at minimunin total cost (i.e., be on the production possibility curve) requires that each firm produce at the minimum of its average cost curve. ${ }^{5}$

"We assume that the firm regards indusiry output as a parameter, unaffected by its own actions. This is identical in spirit to the assumption under which a firm in perfect conpetition assumes that exparsion of its own output will nol affect market price.

${ }^{4}$ Since $n$ may consume only integral values, the condition satisfled by $n^{*}$, the cost minimizing number of firms, is

$$
\Delta T C_{n^{*}-1, n^{*}} \leq 0 \leq \Delta T C_{z^{*}, n^{*}+1}
$$

I'erforming the dilference operations on equation 2 and dividing by $n^{*}$ gives the condition

$$
\left.\left.\Delta C_{n^{*},-1, n^{*}}+\left(1 / n^{*}\right) C \mid Q /\left(n^{*}-1\right), Q\right] \leq 0 \leq \Delta C_{n^{*}, n^{*},-1}+\left(1 / n^{*}\right) C \mid Q /\left(n^{*}+1\right), Q\right] .
$$

Since this closely approximates equation 3 for large $n$ it is obvious that the propositions advanced in the texi could have been proved without treating $n$ as a continuous variable. However: doing so would have made the exposition somewhat cumbersome.

${ }^{6}$ This is where Kemp went wroing athough it is cunntersome to show his exact error without reproducing his entire graphical analysis. Basically in const"ucting an average cost "envelope" 
The second condition for Pareto-optimality is that production take place where marginal social cost is equal to price. This requires that:

$$
\begin{aligned}
P=\partial T C / \partial Q & =n\{\partial C /(\partial Q / n) \cdot[(\partial Q / n) / \partial Q]+(\partial C / \partial Q)\} \\
& =n\left[\left(C_{1} / n\right)+C_{2}\right]=C_{1}+n C_{2},
\end{aligned}
$$

where $C_{2}=\partial C / \partial Q$.

'Thus the marginal social cost of a unit increase in output is the sum of private marginal cost, plus $n$ times the effect of a one-unit increase in output on the costs of cach firm in the industry. (For an external economy, $C_{2}$ is negative.) For allocative efficiency we require that production take place where price equals this marginal social cost.

If we grant a per-unit subsidy of $-n C_{2}$, we have the following:

$$
P^{\prime}=P-n C_{2}
$$

where $P$ is the market price and $P^{\prime}$ is the price including the subsidy.

But competitive equilibrium in an industry with free entry requires:

$$
P^{\prime}=M C=A C \text {. }
$$

Therefore, the first condition for Pareto-optimality, i.e., all frrms producing at the minimum of their average cost curves, is fulfilled.

Moreover, combining equations 6 and 7 , and recognizing that $C_{1}$ is private marginal cost, we have:

$$
P=C_{1}+n C_{2}
$$

thereby fulfilling the second condition for Pareto-optimality, i.e., that production take place where marginal social cost is equal to price.

Thus we have shown that, although real external economies in production are incompatible with Pareto-optimality in a competitive industry with free entry and exit, a simple Pigovian per-unit subsidy (tax for diseconomies) is adequate to "repair" the situation.

\section{References}

Goetz, C. J. and J. M. Buchanan. "External Diseconomies in Competitive Supply." American Economic Review LXI (1971), 883-90.

Kemp, M. C. "The Efficiency of Competition as an Allocator of Resources: I. External Economies of Production." Canadian Journal of Economics and Political Science 21 (1955), $30-42$

for the industry in the case of frec entry, he carried over a set of equilibrium points from the case of a fixed number of firms without noticing that the equilibria from the latter case $\left(X_{1}, X_{2}, X_{3}\right)$ would not exist if the number of firms were allowed to vary through entry or exit. Thus, using Kenp's notation, if industry output were $n X_{1}$, we would not, in fact, have $n$ firms each producing $X_{1}$, but $n^{\prime}$ firms $\left(n^{\prime}>n\right)$ each producing less than $X_{1}$, thereby lowering total social costs of producing $n X_{1}$. Thus any point on the true "envelope" of average industry costs, would always correspond to just the right number of firms each producing at minimum average custs. 